\title{
STRATEGIC ALLIANCES' FEATURES AND IMPACTS ON THE COMPETITION OF THE SWITCHED TELEPHONY IN BRAZIL ${ }^{1}$
}

\author{
Walter Tadahiro Shima
}

\section{SOME GENERAL CHARACTERISTICS OF THE GLOBAL STRATEGIC ALLIANCES}

One of the new elements in the global oligopolistic competition is the formation of strategic alliances understood as a cooperation agreement between two or more dispersed agents, under a spatial point of view, which establish to each other not-hierarchic cooperative procedures in order to interchange information and obtain reciprocity of actions (BRITO, 1996, p. 15). The alliances can also be understood as a partnership agreement that searches the increase of the competitive strategies' effectiveness among the organizations that interact by means of mutual and beneficial exchange of technologies, qualifications and/or products. Basically, the characteristics of strategic alliances are:

a) two or more companies joined to accomplish a set of combined goals, however they remain independent before and after the alliance;

$1 \quad$ Article presented at " 19 th Annual ICFC Conference - An International Communications Conference for Marketing, Forecasting \& Demand Analysis. The Digital Economy: Forecasting, Economics and Marketing Challenge for the Communications Industry". Washington DC, USA, June 26-29, 2001.

2 Lecturer at Universidade Federal do Paraná, Brasil. E-mail: wshimab@sociais.ufpr.br 
b) the companies share the benefits from the alliances and control the completeness of specified tasks (this aspect is one of the most difficult of managing related to alliances); and

c) the allied companies continually contribute to one or more crucial strategic areas of the alliance;

This article analyzes the arrangements among operators, which use strategies to be able of competing in the global trade. In this sense, the objective of the alliances is to enlarge the several operators' economic forces for a greater exploration of the worldwide markets. Thus, the huge operators spread their technologies and interconnection standards of net. In other terms, they make the attempt of global operators mold the future digital economy possible.

The fast development and diffusion of technologies of information are factors that strengthen the strategic alliances. The utilization of such technologies naturally results in the organization of equipment in a network of optical fibers and antennas. That organization form, from new technologies of communication, spreads itself to determine the dynamic relationship among the operators. This way, one can deduce that the new technical organization of the network, which includes digital standards, is applied to the institutional organization that embodies the relationship among operators. On the other hand, the technical organization form of the net is applied to the organization of an economical network.

The alliances discussed here, along with technologies of information, constitute a kind of paradigm change. A wide spectrum of technical and economical advantages arises due to the great diffusion of such technologies, changing the whole system behavior (FREEMAN, 1991, p. 508). The firms can commit and/or invest resources, set up interchanges all the time, define agreements and establish strategies at any time in the world due to the communication, which allows the exchange of simultaneous information anywhere around the world. In other words, the telematic increases substantially the mobility power of capitals. The alliances ensue from the development of competition that is global. Nowadays, the competition is not limited in a country or among its capitals anymore, but it is global in its composition. The capitals are allied to invigorate competitive strategies as well as the new technologies in communication allow the establishment of alliances through a virtual integration.

In fact, the reality is just that the alliances among operators became necessary because their traditional corporative clients have become global along the years; the multinational corporations are no longer 
concentrating their key-activities in only one country, mainly the R\&D ones, as a result of the appropriation and protection. This way, all activities were decentralized in a perspective of world division of several internal activities to corporations.

Thus, those corporative clients have been demanding services and solutions of communication of global nature. In other words, sophisticated solutions that allow corporative communication simultaneously broadcast at any time, among several points in the world where several headquarters are located. These global services are characterized by end-to-end services that make the point-to-point communication of a one-count client of only one operator possible. It is a kind of "one-stop-shopping", in other words, the user does not know the implication of cooperative/competitive arrangement among several operators. The real objective of the alliances is the construction of a Global Virtual Private Network (GVPN), which is a virtually unified net with only one administration while the physical infrastructure can belong to several operators. It is virtual because it is programmed to interconnect several geographically dispersed nets and, consequently, to provide a variety of solutions for any customers.

Concluding, the operators need to have an available physical infrastructure such as: antennas, optical fibers, centrals, cables and satellites spread around the world and capable of offering efficient services as they used to "formerly" (when the clients were restricted to a certain country) and the only way of acquiring it is, necessarily, by means of strategic alliances that make GVPN's formation possible because no operator can be the only owner of such an enormous infrastructure. The feasibility for the formation of GVPN can be either given by means of singly direct acquisition of infrastructure or by means of association, depending on how the switched telephony is organized in the country.

\section{THE INSTITUTIONALIZATION OF THE COMPETITIVE ENVIRONMENT AND THE ENTRANCE OF THE STRATEGIC ALLIANCES IN SWITCHED TELEPHONY IN BRAZIL}

Before switched telephony privatization, in 1998, the public holding "Telebras in all national territory, explored the telephony services. By then, there were two possibilities of privatization:

$1^{\text {st }}$. To sell "Telebras" as an unbroken company; or

$2^{\text {nd }}$. To sell it divided. 
SHIMA, W. T. Strategic alliances' features and impacts on the...

Table 1 - REGIONS, COVERAGEAREAAND REGIONAL OPERATORS FOR SWITCHED TELEPHONY SERVICE IN BRAZIL

\begin{tabular}{l|l|c}
\hline REGION & COVERAGE AREA & OPERATOR \\
\hline Region I & $\begin{array}{l}\text { States: Rio de Janeiro, Minas Gerais, Espírito Santo, } \\
\text { Bahia, Sergipe, Alagoas, Pernambuco, Paraíba, } \\
\text { Rio Grande do Norte, Ceará, Piauí, Maranhão, Pará, } \\
\text { Amapá, Amazonas and Roraima }\end{array}$ & $\begin{array}{c}\text { Telenorte Leste } \\
+ \\
\text { authorized } \\
\text { operators }\end{array}$ \\
\hline Region II & $\begin{array}{l}\text { States: Santa Catarina, Paraná, Mato Grosso do Sul, } \\
\text { Mato Grosso, Tocantins, Goiás, Distrito Federal, } \\
\text { Rondônia, Acre and Rio Grande do Sul }\end{array}$ & $\begin{array}{c}\text { Telecentro Sul } \\
+ \\
\text { authorized } \\
\text { operators }\end{array}$ \\
\hline Region III & São Paulo State & $\begin{array}{c}\text { Telesp } \\
+ \\
\text { authorized } \\
\text { operators }\end{array}$ \\
\hline Region IV & The whole national territory for long distance operation & $\begin{array}{c}\text { Embratel } \\
+ \\
\text { authorized } \\
\text { operators }\end{array}$ \\
\hline
\end{tabular}

SOURCE: 〈www.anatel.gov.br>

Finally, the second option prevailed. ${ }^{3}$

Thus, it was established that Telebras would be broken into four big regional operators (see table 1):

At the first moment, concessions were sold to the capitals that bought the regional assets of "Telebras". Therefore, they are considered switched telephony concessionaire capitals and are submitted to the Public Juridical Regime. At the second moment, authorizations were sold to capitals that had intended to be the second operators to enter the competition with their own assets. Thus, these operators received the denomination of mirrors and are submitted to the Private Juridical Regime.

The main differences between Public and Private Juridical Regimes refer to the obligations and are the following (see table 2):

3 Within the official regulatory perspective, the first possibility of sale was rejected because the purchaser would probably have an enormous monopoly power that could hardly be broken by other companies. The new purchaser, the only infra-structure owner, could rapidly build impassable barriers to the entrance. 


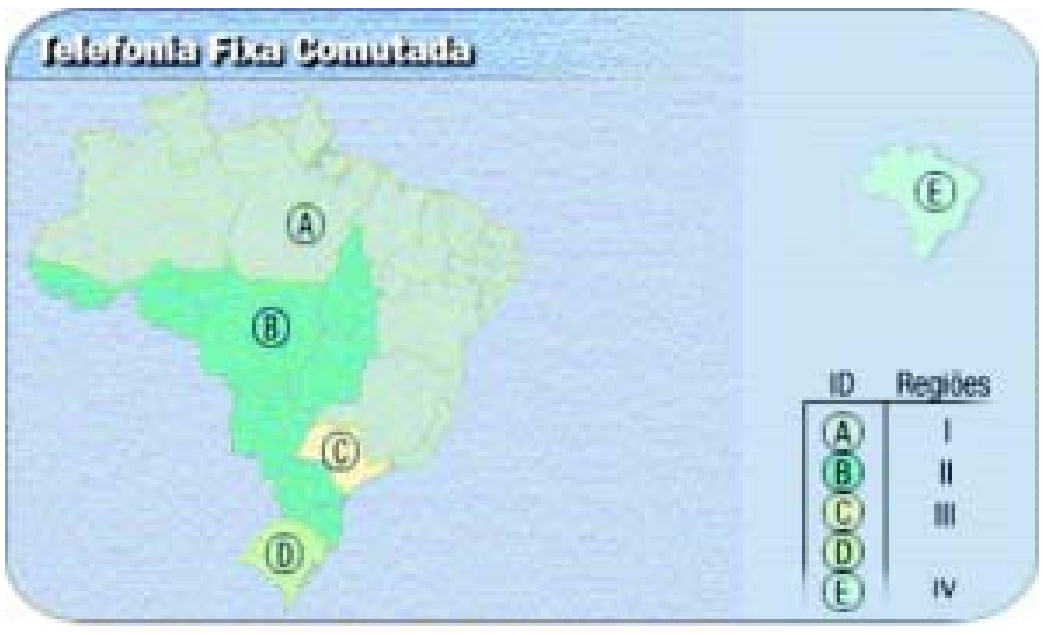

Table 2 - BASIC DIFFERENCES BETWEEN PUBLIC AND PRIVATE JURIDICAL REGIMES

\begin{tabular}{c|c}
\hline Public Juridical Regime & Private Juridical Regime \\
\hline Concession & Authorization \\
\hline $\begin{array}{c}\text { Obligations of continuity and universalization } \\
\text { Pre-determined validity that can be renewed only once for } \\
\text { more 20 years }\end{array}$ & No obligations of continuity and universalization \\
\hline Submitted to a tariff regulation & No pre-determined validity \\
\hline
\end{tabular}

SOURCE: 〈www.anatel.gov.br>

This way, with the installation of concessionaires and authorized operators, the first moment is distinguished by duopolic competition in the regions $^{4}$ (see table 3):

4 According to the "Lei Geral das Telecomunicações (LGT)" - General telecommunications Law: new mirrors will be able to enter all regions from 01/01/2002; the concessionaries will be able to enter other regions from 01/01/2004, (such entrances can be antecipated to 01/01/2002 if all concessionaries accomplish their compulsory goals of universalization). 
Table 3 - ORGANIZATION OF DUOPOLY IN THE MODALITIES OF SWITCHED TELEPHONY UNTIL 2001

\begin{tabular}{|c|c|}
\hline MODALITIES OF SWITCHED TELEPHONY & COMPETING OPERATORS UNTIL 2001 \\
\hline Local & $\begin{array}{c}\text { Local service concessionaire } \\
\mathrm{x} \\
\text { local service mirror }\end{array}$ \\
\hline Intro-regional long distance & $\begin{array}{c}\text { Long distance concessionaire } \\
\text { X } \\
\text { Long distance mirror } \\
\text { X } \\
\text { Local service concessionaire } \\
\text { X } \\
\text { Local service mirror }\end{array}$ \\
\hline Inter-regional long distance & $\begin{array}{c}\text { Long distance concessionaire } \\
\mathrm{X} \\
\text { Long distance mirror }\end{array}$ \\
\hline Long distance international & $\begin{array}{c}\text { Long distance concessionaire } \\
\mathrm{X} \\
\text { long distance mirror }\end{array}$ \\
\hline
\end{tabular}

From the Brazilian regulatory mark, the study of the global strategic alliances' behavior in switched telephony becomes necessary due to the new competitive environment created.

\section{THE GLOBAL STRATEGIC ALLIANCES AND THEIR STRATEGIES OF ENTRANCE IN THE BRAZILIAN MARKET}

The strategic alliances of "Telefônica" - the Pan-American net

"Telefônica", the concessionaire in the Region III, accomplished the most important strategic alliance in the Brazilian switched telephony. It is considered the most important because one of its main goals is to become leader in the Latin-American market. In this sense, "Telefônica", along with "Telesp", acquired the concession to operate in the largest region in Brazil, São Paulo State. According to table 4, one can observe that Telefônica has been acquiring a row of operators in other countries in Latin America, due to its intention of leadership in telecommunications in general, it acquired one row of mobile telephony operators. 
Table 4 - YEAR OF PRIVATIZATION, COUNTRIES AND PRIVATIZED OPERATORS OR WITH THE PARTICIPATION OF TELEFÔNICA

\begin{tabular}{l|l|l}
\hline YEAR OF PRIVATIZATION & COUNTRIES & $\begin{array}{l}\text { PRIVATIZED } \\
\text { OPERATORS }\end{array}$ \\
\hline 1990 & Chile & CTC \\
\hline 1990 & Argentina & Telefonica \\
\hline 1994 & Peru & ENTEL \\
\hline 1994 & Peru & CPT \\
\hline 1991 & Porto Rico & TLD \\
\hline 1991 & Venezuela & CANTV \\
\hline unavailable & El Salvador & Intel \\
\hline 1998 & Brazil & CTBC \\
\hline 1998 & Brazil & Telesp Celular \\
\hline 1998 & Brazil & Telebahia Celular \\
\hline 1998 & Brazil & Telerj Celular \\
\hline 1998 & Brazil & Telest Celular \\
\hline 1998 & Brazil & Telergipe Celular \\
\hline
\end{tabular}

SOURCE: Almeida, 1999, p. 14, Telefonica e <www.Telefonica.es>

Portugal Telecom, MCI WorldCom and IBM make up this alliance.

\section{Portugal Telecom}

In Brazil, the alliance of Telefonica with Portugal Telecom began in April, 1997. The first goal of this alliance has been to establish strategies that strengthen and prevent other operators from entering the Iberian Peninsula because of the competitive pressure among European operators. As a second goal, according to several published reports at www.telefónica.es, the alliance intends to make its expansion to the Latin America possible, mostly in Brazil, Morocco and afterwards the whole market in North Africa. As a result of this agreement, the tariff between both countries has become cheaper as the connections are now considered inter-provincial (interstate), not international.

There were some previous actions that contributed to this strategic alliance. For example: a) Telefonica has $15 \%$ of "Contactel", the company that owns a license to operate radio-call in Portugal; b) the constitution of the systems engineering company, Telefonica Systems of Portugal in 1995. Telefonica International with $25 \%$ and Telefonica Systems, which belongs to 
the Holding Telefonica, with 75\%. In other words, a Spanish capital company is operating in Portugal; and c) the cable optic fiber inauguration connecting both countries between Vigo and Porto.

One fact that is visible, due to its role within this alliance, is that Portugal Telecom has to follow a hierarchy commanded by Telefonica. Two facts contribute to this affirmative:

One fact is the organization/adaptation of the regulatory marks imposed by the Telecommunications General Law (LGT), which allowed the acquisition of Telesp Celular by Portugal and made the indirect leadership of Telefonica over most part of telecommunications in São Paulo state possible. Telefonica couldn't buy the concession of Telesp Celular legally since it owns $56.66 \%$ of the common stocks of Telesp; according to LGT, such a fact is enough to prevent her from entering this segment. However, the "by-pass" from the legislation was possible because of the alliance that happened out of the country, facilitating the control of the switched telephony and the mobile service, even if the official controller is Portugal Telecom. This explains why there is a crossed stock agreement between Telefonica, which owns $3.5 \%$ of Portugal Telecom, and Portugal Telecom, which owns 1\% of Telefonica. On the other hand, Portugal is the second biggest stockholder in Telesp Fixa.

The other fact is that Telefonica has strategies in order to control the capital through actions of international expansion where Portugal takes part. Recently, Telefonica entered Morocco by means of concession purchase, while Portugal entered with a minority participation. Moreover, Portugal enters as an ally with Telefonica in the alliance with MCI WorldCom. Such a fact is visible in a report done by MCI and WorldCom showing that Telefonica and MCI WorldCom decide the fate of Portugal Telecom inside the alliance:

\footnotetext{
Also, Telefonica, MCI and WorldCom have agreed with Portugal Telecom that the four parties will initiate detailed discussions aimed at including Portugal Telecom into the various business plans announced by Telefonica, MCI and WorldCom today. The focus of these arrangements will be to complement the parties' existing activities (www.wcom.com).
}

The alliance is hierarchical with reversible net, shaped to exploit punctually complementary competence (BRITO, 1996, p. 33) (in the case of entrance in markets where both operators have cultural competitive advantages). Portugal and Telefonica are strategic allied because of the neighborhood in the Iberian Peninsula and the necessity of jointed strategies to face the European competition, by means of expansion to other markets, though the first one does not have conditions of negotiating evenly the planning of strategies. 
Actually, Portugal is not hierarchically direct subordinated to Telefonica, yet there is an alliance where the strategic interests are more related to Telefonica's direct interests, so Telefonica is clearly the leader. The coalition has characteristics of opportunism by Telefonica as Portugal participates the alliance due to its cultural proximity to one of its largest markets, Brazil, and in the sequence the Portuguese-speaking African countries. On the other hand, Telefonica intends to enter Latin America markets and to acquire competitive capacity in Europe, justifying then its interests of including Portugal as one of its alliances around the world, that is, Telefonica "accepts" Portugal as an allied not because this company can contribute in terms of technology or market capacity, for instance, but due to a possible enlargement of market. In short, Portugal benefits from the alliance indirectly, because of its geopolitics situation and strategies.

Another important action, within this alliance, in order to build a global net is the construction (in this case for exclusive use) of the system ATLANTIS-2 - with submarine cables and optical fibers that connect Spain and Portugal to Argentina and Brazil, accomplished in 1999. The construction involved an up-to-date net with high capacity, the most advanced maintenance system, which has the flexibility of being adapted to current and future developments of multimedia softwares.

The goals of this alliance can be synthesized in the picture below:

Chart 1 -STRATEGIC ALLIANCE GENERAL GOALS TELEFÓNICA/PORTUGAL TELECOM

To build a physical infrastructure that strengthen and complete its virtual private net: the cable Atlantis - 2 enlarges the net capacity because it includes the Latin American market.

To define strategies of competition that benefit both companies to face the intro-European competition in Iberica Peninsula.

To set up crossed stock agreements.

To expand to new markets: Brazil, Morocco and North of Africa.

To exploit together their own markets: TELEFÓNICA renders services to Portugal and PORTUGAL TELECOM renders services to Spain.

To build a Virtual Private Net: both operators can work to their corporative clients using the same net with agreements and facilities (interconnection and price).

To make possible the market concentration by-passing the regulation: for example, the purchase of Telesp Celular.

SOURCE: interview at Telesp and searches at <www.pt.com> 


\section{WorldCom}

This alliance includes Telefónica, Portugal Telecom, and MCI WorldCom. ${ }^{5}$ It was signed in March, 1998, with the European telecommunications market liberation, allowing the competition among the Baby Bells and fusions among them. Such an alliance aims to enlarge the net extension and the three operator's competitive power, as this agreement permits them to enter the new telecommunications market in America and Europe. Also, there are crossed stock agreements where Telefónica answers for , although with minority, current and future business of MCI WorldCom in Europe, by means of $10 \%$-participation in a new company (that belongs to MCI WorldCom) created to manage their interests in that continent. Furthermore, Telefónica gets the right of buying $46 \%$ in a firm of $M C I$ WorldCom, in Italy, and both of them ally to explore services in East and Southeast of Europe, under the leadership of MCI WorldCom that owns 51\% of the common stocks. MCI WorldCom also participates with $10 \%$ in TISA. Thus, through that alliance, by means of $M C I$, Telefónica aims to reach and to become leader in all Spanish-speaking countries in South America. At the beginning, they also intended to participate together in Telebras' auction, but the alliance did not come out right because of $M C I$ 's financial problems.

The alliance didn't come out well for that strategy, but it adopted other more effective alternative in terms of net extension control and market concentration, that was the concession of the Region IV, exclusively obtained by MCI WorldCom. Therefore, that alliance dominates Telesp and Embratel (it dominates local and long distance services, exactly what LGT aims to restrict). However, there are internal conflicts and located competitions between them, even being allied abroad.

Recently, Telesp had problems concerning net rental and interconnection with Embratel, because both operators work separately and compete in switched telephony long distance modality, intro-regional. This alliance has a wider goal, which is net concentration to build a VPN that interconnects global allied clients with common standards and facilities. In addition, the matters related to competition strategies, conformation of market

5 Initially, in april, 1997, this alliance was established among British Telecom (BT), MCI and Telefónica. When WorldCom bought MCI, BT withdrew from the alliance, only Telefónica and MCI remained. 
structure, and innovations in services in Brazil run independently and, if necessary, with competitive confrontation, more or less intense, depending on the regulatory mark. However, one important point here is just that the alliance creates possibilities of internal, future agreements (in Brazil), facilitating the entrance of mirrors in several Regions, the exploration of new services and the formation of groups in order to diminish competition in the intro-regional market.

The goal, regarding the market expansion, is to complement their nets to work in the global corporative market, in other words, to build a VPN. According to Bert C. Roberts, Jr., MCI President, MCI expansion to Europe will occur by means of Telefónica.

The partnering of WorldCom, Telefónica and MCI is a win for customers, (...) each bringing value through facilities, reach and product. Today's announcement" (related to the alliance formation) "represents a new era of communications competition in both Europe and the Americas" (...). "Together, we will utilize existing facilities and build new networks in emerging markets to support the explosive growth of communications services around the world (www.wcom.com).

As a matter of fact, both companies have complementary interests because:

- WorldCom aims to expand its broadband physical net around the world;

- Telefónica and $\mathrm{MCI}$ aims to strengthen the capacity of providing global connectivity for their global clients.

Therefore, Telefónica and MCI distribute services to their global clients through WorldCom's net, which also rakes in because it provides broadband network services by means of Telefónica and $M C I$.

One relevant point concerning the alliance is that $\mathrm{MCI}$ chooses Telefónica as its partner, when it could have opted for any other larger, highlighted, European, technologically updated operator, such as: France Telecom, Deutsche Telekom, Telecom Italia, British Telecom. These operators are much bigger than Telefónica (Table 5). However, such a choice was strategic because $M C I$ intended to reach the Hispanic consumers in the United States, who represent an increasing potential of market. This market gathers in a whole of 29 million people and represents $8 \%$ of all long distance services in the United States, being evaluated in US\$ 93 billion. This way, the only 
operator capable of achieving that goal is Telefónica, because it is the biggest supplier of telecommunications services for Spanish-speaking countries, reaching more than three hundred million people by means of its net. From this deal, MCI WorldCom, with 70\%, and Telefónica, with 30\%, created a joint-venture, which aims to provide customized services, and to promote exclusive campaigns of marketing to all Hispanic markets around the world (www.wcom.com).

Another important point is that MCI WorldCom's objective is in line with Telefónica's. Telefónica aims to reach north American market and the only possible way is by means of the alliance, otherwise it would be impossible due to the intense competition in the United States, where the competitors are powerful operators with enormous capacity of constructing high barriers to the entrance, via technology, diversification of services, and prices.

Those convergent interests in building a VPN in Latin America made Telefónica-Panamericana MCI or Pan-american Net possible as an enterprise, which is led by Telefónica with $51 \%$ of the common stocks and aims to build an updated digital net to connect the biggest business centers in Latin America, considering possible regulatory changes and demands for new services in the Region (This explains all the privatizations in the Region). The net will consist of high-speed, optical-fiber cables and sophisticated intelligent centrals in order to support the heavy traffic of data and voice.

Table 5 - THE FIFTEEN LARGEST OPERATORS IN THE WORLD - 1998

\begin{tabular}{c|c|c}
\hline OPERATOR & COUNTRY & BILLING (US\$ bi) \\
\hline NTT & Japan & 71,5 \\
\hline AT\&T & USA & 51,3 \\
\hline Deutsche Telekom & Germany & 37,6 \\
\hline Bell Atlantic & USA & 30,1 \\
\hline BT & UK & 26,2 \\
\hline France Telecom & France & 26,1 \\
\hline SBC & USA & 24,8 \\
\hline Telecom Italia & Italy & 24,2 \\
\hline GTE & USA & 23,2 \\
\hline Bell South & USA & 20,5 \\
\hline MCI & USA & 19,6 \\
\hline DGT & China & 17,1 \\
\hline Ameritech & USA & 15,9 \\
\hline Telefónica & Spain & 15,5 \\
\hline US West & USA & 15,2 \\
\hline
\end{tabular}

SOURCE: ITU in Gazeta Mercantil (28 e 29/11/98). 
The expectation for 2001 is that the net can link most of those big centers in Latin America, facilitating the entrance and the exit from the net, for connections of MCI WorldCom and Telefónica. That is, all the other telecommunications nets of these three operators can connect to each other easily, forming a Pan-American net, due to standardization of interfaces and protocols. Another enterprise that arose from this alliance, with the participation of Telefónica (50\%) and MCI SystemHouse (50\%), is a company of MCI WorldCom (www.wcom.com) that supplies services of integration systems to corporative clients and governments in all Latin America.

The goals of this alliance can be synthesized in the chart bellow:

Chart 2 - TELEFÓNICA/MCI WORLDCOM STRATEGIC ALLIANCE'S GENERAL GOALS

To establish crossed stock agreements.

To expand both nets virtually a physically, through the construction of a VPN to reach the corporative market by means of investments and infrastructure.

To make market concentration possible: acquisition of Telesp and Embratel.

To facilitate the crossed entrance in both markets: MCI WorldCom enters European market and part of Latin America, via Telefónica's net, rendering services in these new corporative markets in those

Regions, whereas Telefónica enters the United States reaching Spanish-speaking countries. There will be used the Pan-American Net in Latin America, which is a VPN.

To provide services of system integration, via Pan-American net, for corporative markets and governments in Latin America.

SOURCE: Based on interviews at Telesp and searches on <www.wcom.com>

\section{IBM}

All that Telefónica's expansion requires necessarily a technological support. The net construction by those alliances implies a row of developed systems, standards and technologies. Thus, one of the technological partners in these alliances is IBM. In March 1999, Telefónica and IBM made an agreement in order to use Telefónica's infrastructure to offer corporative solutions about nets and protocols IP (Internet Protocol) in Spain and Latin America. The objectives of the net (IP) are:

1. To create digital solutions that allow the storage, administration and distribution of data, image and music;

2. To develop and to implement global plans of distribution of services and telematic solutions for Telefónica;

3. To develop solutions for cellular telephony operators.

IBM visualizes Telefónica's net widespread dimension in formation in Europe and in Latin America and visualizes it as a great opportunity of 
diffusion of its own technologies. One of its reports says: "Telefónica and $I B M,(\ldots)$, have the complementary competencies necessary to jointly develop this business in the Spanish market, with an eye toward future expansion to other markets, specifically Latin America" (www.IBM.com).

Both parts will contribute for the alliance in the following way:

- Telefónica will make available all its market, its knowledge, and its experience in services and applications for data transmission, about net IP, in several industries and enterprises in Spain and South America;

- IBM (specifying the items 1 and 2 above) will offer the development of adaptable applications to the new horizontal and flexible models of administration production organization. In a global telecommunications environment, this development is related to the customized use by all kinds of small, medium and big companies, in the Internet (real time), for communication among partners, suppliers and clients, for information exchanges and for commercial transactions. Such services are: $e$-business and $e$-commerce $e^{6}$ and other resultant services, such as: Web Selling, EDI/Web EDI, Web enabled payments. In addition, such services involve the development of safety systems of information that allow the product exhibition and services in the Internet (www.IBM.com).

In conclusion, all kinds of clients of Telefónica will have available an amount of customized products and services, such as:

- interactive financial services;

- virtual safety services;

- virtual connections for industries with suppliers, videoconference;

- virtual rooms for broadband conference to support videos for training and promotion of high definition images;

- internal corporative communication (Intranet) by means of implementation of the standard application IBM/Lotus, Lotus Notes (e-mail, corporative notebook, internal communication, information manager, Web browsing).

6 About the perspective and development tendencies concerning these services in Brazil see (TIGRE, 1999). 
There are already three products that can be used by Telefónica's corporative clients, as a result of this alliance: Novacom Aptiva, Novacom IBM PC and Novacom Router (www.telefónica.es), which represent corporative solutions of connection by means of ISDN. They are easily installed and configured by the user and are adaptable to any kind of equipment.

Briefly, Telefónica offers the market and IBM offers technological solutions. The alliance assures to Telefónica a partnership that makes possible the construction of an updated VPN, which gives Telefonica equality of conditions with other operators and global alliances.

The goals of this alliance can be synthesized in the following picture:

Chart 3 - STRATEGIC ALLIANCE'S GENERAL GOALS TELEFÓNICA/IBM

\begin{tabular}{c}
\hline To develop flexible and customized services and new products. \\
\hline To develop telematic (IBM). \\
\hline To diffuse IBM standard through Telefónica's VPN. \\
\hline To keep the technological actualization of Telefónica's VPN. \\
\hline To standardize the routines of communication of Telefónica's net with IBM pattern.
\end{tabular}

SOURCE: elaborated by the author based on consultations in <www.Telefonica.es> and <www.ibm.com>

\section{The strategic alliances of Telecom Italia}

The second important strategic alliance that entered in the Brazilian market is Telecom Italia's. It is the second, once it didn't have a strategy so aggressive as Telefonica did. It entered in Telecentro Sul through the purchase of $19.99 \%$ of the common stocks; Telefonica bought $56.66 \%$ of Telesp. Its main intention is to increase the secondary participation in several regions and in the mobile communication, while Telefonica intends to consolidate its initial leadership in a specific region (Region III).

In February, 1998, after the privatization of Telecom Italia, the new board of directors established a basic goal: the revision of operator competitive position. The reasons of this was the recognition of the evolution of international alliances, the increasing pressure towards the deregulation in the United States, the rapid technological development involving alternative net infrastructures (satellites, cables, Internet) and the need to emphasize the innovation in services (www.telecomitalia.it). It was a new perspective of a new open Italian market and acquisition of competitive capability. 
In this sense, Telecom Italia tried to build alliances and acquisitions in the Latin America markets and Europe and secondarily in the other markets. According to Table 6, it can be seen the expressive penetration of Telecom Italia in these two continents.

Table 6 - PERCENTAGE PARTICIPATION OF TELECOM ITALIA IN THE PRIVATIZED OPERATORS IN LATIN AMERICA

\begin{tabular}{c|c|c}
\hline COUNTRIES & PARTICIPATION \% & OPERATORS \\
\hline Argentina & 60,00 & Telecom Argentina (north) \\
\hline Bolivia & 50,00 & ENTEL \\
\hline Chile & 20,00 & ENTEL \\
\hline Cuba & 29,29 & ETEC S.A \\
\hline Spain & 21,66 & Retevision \\
\hline Spain & 39,10 & Retevision Movil \\
\hline France & 49,00 & Mobilecom \\
\hline Austria & 25,00 & STET Hellas (telefonia móvel) \\
\hline Greece & 58,14 & Telekom Serbia \\
\hline Serbia & 29,00 & Telefonia móvel \\
\hline Republic Theca & 6,00 & No available \\
\hline China and India & No available & Golden Lines (long distance)
\end{tabular}

SOURCE: 〈telecomitalia.it>

\section{Cable and Wireless}

The second Telecom Italia's alliance is the one announced in April, 1998, with Cable \& Wireless (CW), in Britain. Inside the expansion strategy to Latin America, that alliance allows the entrance of Telecom Italia in the Caribbean Region, where cw has strong performance by means of control and participation in all operators of the region. On the other hand, the alliance reinforces Cw's expansion to Europe, Asia and the United States.

This alliance doesn't have strong links as the previous one does because there isn't a crossed stock agreement, but, it has the entrance of Telecom Italia in CW's holding and, on the other hand, the right to use Telecom Italia's VPN by CW. The entrance of Telecom Italia in Cw occurs through the purchase:

- $20 \%$ of Cable \& Wireless West Indies Limited;

- $5 \%$ of Cable \& Wireless Inc. in the United States and

- $20 \%$ of $\mathrm{Cw}$ in Bouygues Telecom in France (Telecom S.A).

The basic goal in this alliance is the formation of vPN to assist for corporative services. Cw looks upon Telecom Italia as a strategic, allied partner 
because, through it, $\mathrm{CW}$ penetrates in other European continental and South America markets. And Telecom Italia also looks upon CW as a strategic allied partner because it practically completes its own penetration in Latin America with the entrance in the Caribbean region and in British, French and Spanish markets.

The goals of this alliance can be synthesized in the following chart:

Chart 4 - GENERAL GOALS OF TELECOM ITALIA/CABLE \& WIRELESS - STRATEGIC ALLIANCE

\begin{tabular}{c}
\hline To expand the VPN through the countries where they operate \\
\hline To explore new markets \\
\hline To strengthen CW's global insertion \\
\hline To complete the entrance of Telecom Italia in Latin America \\
\hline To hasten the entrance of Telecom Italia in Britain, France and Spain
\end{tabular}

SOURCE: based on searches: <www.telecom italia.it>

\section{WorldCom - North American Virtual Private Network}

A second alliance, (considering the Pan American as the first one) where MCI WorldCom participates, was formed in March, 1999, with Bell Canada. ${ }^{7}$ The goal is the same: to provide global corporative services. That alliance along with the Pan American complete the WorldCom's strategy to build a global network. It is necessary to remember that MCI has already had a strong penetration, through its own net, in Europe and Asia-Pacific for all kinds of telecommunications solutions. The alliance strategy is the strong entrance of MCI WorldCom in Canada with a great amount of global solutions. All corporations in North America will have closed a deal with the alliance and a single operator for voice and data services, as well as discounts in the others global services supplied by MCI WorldCom On-Net subsidiary.

The entailed interests that sustain the alliance are:

- MCI WorldCom offers its VPN of high capacity managed by the subsidiary WorldCom On-Net and concedes the access to Bell Canada to attend the United States and the rest of the world;

- Bell Canada spends 7 million on residential and corporative clients.

7 Bell Canada is the biggest telecommunications operator in Canada and renders services in Ontario and Quebec. 
This way, Bell Canada becomes an exclusive distributor of $M C I$ WorldCom's solutions to all its clients in Canada. On the other hand, Bell Canada renders services to their clients in other countries, through $M C I$ WorldCom network.

The goals of this alliance can be synthesized in the following chart:

Chart 5 -MCI WORLDCOM/BELL CANADA - STRATEGIC ALLIANCE'S GENERAL GOALS

a) To create a North American VPN

b) To make feasible the crossed entrance of markets: MCI WorldCom in Canada and Bell Canada in the United States, for all kinds of services.

c) To complete the amount of services of Bell Canada through MCI WorldCom.

SOURCE: based on searches: 〈www.wcom.com>

\section{CONCLUSION}

One can conclude that, by observing the global strategic alliances established by the operators performing in Brazil, the alliances are not relevant to estimulate a national development in the Brazilian telecommunications. They will not undertake this kind of commitment. Brazil is one more geographical area included inside the strategic alliance's general objectives.

These general goals can be summarized in the following chart:

Chart 6 -STRATEGIC ALLIANCE'S GENERAL GOALS IN THE BRAZILIAN TELECOMMUNICATIONS

\begin{tabular}{c}
\hline To increase the assistance capacity of the national infrastructure \\
\hline To form a VPN to reach global corporative clients \\
\hline To expand to new markets \\
To explore mutually the national markets \\
To concentrate markets (Telesp and Embratel's case) \\
To develop new regional services \\
To complement technology in new services
\end{tabular}

SOURCE: based on searches: 〈www.wcom.com>, 〈www.Telefonica.es>, <www.unisource.com>, <www.telecomitalia.it>, <www.IBM.com>, <www.pt.com> 
The alliances aren't formed with the specific goal of entering the Brazilian market and establishing an autonomous strategy for Brazilian development. Their goal is to increase their markets, and Brazil just constitutes an important part of this strategy.

Therefore, the eventual changes and innovations will occur from the global competition that can be more or less intense, depending on the need of attending the global corporative clients. It involves high added value service. In other words, new investments, intense digitalization and new services will occur while these services are necessary as a strategy to counterattack other global operators in search of new markets.

Thus, a global telecommunications development cannot be explained by the "Invisible Hand", due to the alliance's characteristics and their global strategies. The capitals, in telecommunications, are global oligopolies with great power of concentration. Such oligopolies will concentrate the market while diverting LGT's regulatory objectives through the arising breaches in the regulatory Mark.

\begin{abstract}
Strategic alliances can be understood as a partnership agreement that searches the increasing of the competitive efficiency and its organization among the participants. The alliances search mutual and beneficial interchange of technologies, qualifications and/or products. Basically, the characteristics of strategic alliances are: a) Two or more companies joined to accomplish a set of combined goals, however they remain independent before and after the alliance; b) The companies share the benefits from the alliances and control the completeness of specified tasks (this aspect is one of the most difficult of managing in the alliance); and c) The allied companies continually contribute to one or more crucial strategic areas that concern alliances. This article analyzes the strategic alliances among operators. In this sense, the objective of the alliances is to enlarge the several operators' economic forces for a greater exploration of the worldwide markets. The alliances along with the information technologies constitute a kind of change of paradigm. A wide spectrum of technical and economical advantages arises due to the high intensity of diffusion of such technologies, changing the behavior of the whole system (FREEMAN, 1991, p. 508). The privatization of the switched telephony in Brazil, in 1998, implied an opening in the market for the entrance of strategic alliances, which are leaders in
\end{abstract}


the global competition. This way, the former telecommunication system, Telebras, was divided into four regions; strong global strategic alliances entered three of them. Thus, this report tries to understand the global operators, their nature and relationship abroad, and the impact of such partnership for the development of the Switched Telephony Services in Brazil.

Key-words: strategic alliances, telecommunications, competition, regulation, switched telephony.

\section{RESUMO}

Alianças estratégicas podem ser entendidas como acordos de parceria que busca aumentar a eficiência competitiva e a organização entre os participantes. As alianças buscam o beneficio mutuo de troca de tecnologias, qualificações e/ou produtos. Basicamente a características das alianças estratégicas são; a) duas ou mais companhias unidas para alcançar um conjunto de objetivos previamente combinados, entretanto, elas permanecem independentes antes e depois da aliança; b) as companhias compartilham os benefícios da aliança e controlam as tarefas especificas(esse aspecto é um dos mais difíceis de gerenciar na aliança); e c) as companhias aliadas continuamente contribuem para um ou mais áreas estratégicas da aliança. Esse artigo analisa a aliança estratégica entre operadoras Nesse sentido, o objetivo das alianças é aumentar as forças econômicas das operadoras para explorar o mercado mundial. As alianças juntos com as TI's constituem um tipo de mudança de paradigma. Um amplo espectro de vantagens econômicas e técnicas decorrem em função alta intensidade da difusão das tecnologias, o que muda compartimento de todo o sistema (Freeman, 1991). A privatização da telefonia fixa no Brasil em 1998, implicou a abertura do mercado para a entrada de alianças estratégicas que são lideres na competição global. Dessa forma, o sistema de telecomunicações anterior, Telebrás, foi dividido em 4 regiões: grandes alianças estratégicas globais entraram em 3 delas. Assim, esse artigo tenta entender as operadoras globais, sua natureza e sua relação com o exterior e o impacto dessas parcerias para o desenvolvimento da telefonia fixa no Brasil.

Palavras-chave: alianças estratégicas, telecomunicações, competição, regulação, telefonia fixa. 


\section{BIBLIOGRAPHICAL REFERENCE}

ALMEIDA, M. W. de; BAPTISTA, M. A flexibilização do monopólio das telecomunicações: desafios mitos. São Paulo: IE/Unicamp, ago.1995, 37 p. Discussão, 49.

ALMEIDA, M. W. de; FERREIRA, Jr. H. Regulamentação e privatização das telecomunicações no Brasil: enfoque teórico e comparação internacional. In: ENCONTRO NACIONAL DE ECONOMIA, 26., 1998. Anais... Vitória, 1998. p. 1345-1368.

ALMEIDA, M. W. de. Investimento e privatização das telecomunicações no Brasil: dois vetores da mesma estratégia. Disponível em <www.eclac.cl> Acesso em: mar. 1999.

. Reestruturação, internacionalização e mudanças institucionais das telecomunicações: lições das experiências internacionais para o caso brasileiro. Campinas, 1994. Tese (Doutorado) - IE/Unicamp.

AMERICAN UNIVERSITY. Disponível em: <www.american.edu/carmel/rg4784a/ page2.cfm> Acesso em: 10 jun. 2001.

ANATEL. Disponível em: <www.anatel.gov.br> Diversos acessos.

ATIS. Alliance for Telecommunications Industry solutions. Disponível em: <www.atis.org> Acesso em: 06 jul. 1999.

BAR, F.; BORRUS, M. From public access to private connections: network strategies and competitive advantage in US telecommunications. In: OECD. Information networks and competitive advantage. Volume II: Comparative reviews of telecommunications policies and usage in the USA and Japan. USA: Berkeley Roundtable on the international economy, University of California, 1989, $61 \mathrm{p}$.

. The Future of Networking. A BRIE Research Paper, 16 March 1993.

.Why Competition Is Necessary in Telecommunications and How to Achieve It: The Experience of the Advanced Economies. Working Paper 102. Paper presented to Chinese policy-makers at a meeting organized by the US Information Technology Office (USITO), Beijing, China, 24-25 Sept. 1997.

BAUMOL, W. J. Contestable Market: an uprising in the theory of industry structure. The American Economic Review, v. 72, n. 1, p. 1-15, Mar. 1982.

BERNABÈ, F. Creating europe's global telecommunications powerhouse. Apresentação em Acrobat Reader do Chief Executive Officer da Telecom Italia. Disponível em: <www.telecomitalia.it> Acesso em: jun. 1999.

BRASIL. Lei n. 9472, de 16 de julho de 1997. Dispõe sobre a organização dos serviços de telecomunicações, a criação e funcionamento de um órgão regulador e outros aspectos institucionais. Emenda Constitucional n. 8, 1995. Disponível em: <www.anatel.gov.br>. Acesso em: maio 1998. 
BRITO, J. Rede de firmas: modus operandi e propriedades internas dos arranjos inter-industriais cooperativos. s.n.t, 1996.

CASSIOLATO, J. E. A economia do conhecimento e as novas políticas industriais e tecnológicas. In: LASTRE, H. M. M.; ALBAGLI, S. (Org.). Informação e globalização na era do conhecimento. Rio de Janeiro: Campus, 1999. p. 164-190.

CASTELLS, M. A sociedade em rede. São Paulo: Paz e Terra, 1999. p. 173-221.

CHESNAIS, F. A mundialização do capital. São Paulo: Xamã, 1996. p. 21-208.

COUTINHO, L.; FERRAZ, J.C. (Org.). Estudo da competitividade da indústria brasileira. 2. ed. Campinas: Papirus, 1994, 510 p.

COUTINHO, L. Um projeto para as telecomunicações. Folha de São Paulo, 11 maio 1997.

DODGSON, M. Technological collaboration and innovation. In: DODGSON, M.; ROTHWELL, R. The handbook of industrial innovation. UK: Edward Elgar pub., 1994. p. 285-292.

FREEMAN, C. Networks of Innovators: a synthesis of research issues. Research Policy, v. 20, 1991, p. 499-514.

GASTER, R. et al. Bit by bit - building a transatlantic partnership for the information age. New York: M.E. Sharpe, 1996, p. 3-127.

HARRIS, R. G.; KRAFT, C. J. Meddling through: regulating local telephone competition in the United States. Journal of Economic Perspective, Fall, 1997, v. 11, n. 4 p. 93-112.

HAWKINS, R. Infra-estrutura de informação e comunicações: ambições globais e realidades regionais. In: COUTINHO, L.; CASSIOLATO, J. E.; SILVA, A. L. da. Telecomunicações, globalização e competitividade. Campinas: Papirus, 1995. p. 39-80.

HERRERA, A. Reforma del sector de telecomunicaciones en Brasil: asimetría regulatória, competencia y universalización de los servicios. Trabalho elaborado no âmbito do projeto "Reforma do Estado e Regulação de Setores de Infra-estrutura no Brasil", do Instituto de Economia da Universidade Federal do Rio de Janeiro, dez. 1998, 49 p.

HOBDAY, M. Telecommunications - a "leading edge" in the accumulation of digital technology? Evidence from the case of Brazil. Information Technology for Development, v. 1, n. 1, 1986, p. 23-43.

IBM. Disponível em: <www.IBM.com> Acesso em: 30 jun. 1999.

INFORMATION SOCIETY TRENDS: diversas edições virtuais recebidas por correio eletrônico. Disponíveis em: 〈www.ispo.cec.be〉.

LÉVY, P. As tecnologias da inteligência - o futuro do pensamento na era da informática. São Paulo: Editora 34, 1996, 204 p.

MANSELL, R. The new telecommunications: a political economy of network 
evolution. London: Sage Pub., 1993, 260 p.

Innovation in Telecommunication: Bridging the supplier-user interface. In: DODGSON, M.; ROTHWELL, R. The handbook of industrial Innovation. UK: Edward Elgar, 1994. p. 232-242.

MCI WORLDCOM. Disponível em: <www.wcom.com> Acesso em: 06 jul. 1999. MINISTÉRIO DAS COMUNICAÇÕES. Diretrizes gerais para a abertura do mercado de telecomunicações. Disponível em: 〈www.anatel.gov.br> Acesso em: fev. 1999.

- Programa de recuperação e ampliação do sistema de telecomunicações $e$ do sistema postal. Edição 1997. Disponível em <www.anatel.gov.br> Acesso em: maio 1998.

MINSKY, H. Integração financeira e política monetária. Economia e Sociedade, Campinas, v. 3. p. 21-36, dez. 1994.

MYTELKA, L. K. Dancing with wolves: global oligopolies and strategic partnerships. In: HAGEDOORN, J. Technical change and the world economy-convergence and divergence in technology strategies, Aldershot: Elgar, forthcoming, 1994, 26 p.

PORTER, M.; CAVES, R. E. From entry barriers to mobility barriers. The Quartely Journal of Economics, v. XCI, n. 2, p. 241-261, may 1977.

PORTER, M. A vantagem competitiva das nações. Rio de Janeiro: Campus, 1993, p. 43-83.

Estratégia competitiva: técnicas para análise de indústrias e da concorrência.

5. ed. Rio de Janeiro: Campus, 1991, 362 p.

PROCHNICK, V. Implicações para o Brasil do processo de globalização no setor de serviços de telecomunicações. Boletim de Conjuntura, IE/UFRJ, v. 16, n. 1, p. 5357, abr. 1996.

REVISTA FORTUNE. The Telecom wars for long-distance companies, going local is a grind, p. 136-142, 3 March 1997.

SHAPIRO, C.; VARIAN, H. R. A economia da informação - como os princípios econômicos se aplicam à Internet. Rio de Janeiro: Campus, 1999. 397 p.

SHIMA, W. T.; DE NEGRI. A história da Telepar: progresso técnico, estratégias e mudanças organizacionais. In: CONGRESSO BRASILEIRO DE HISTÓRIA ECONÔMICA/IV CONFERÊNCIA INTERNACIONAL DE HISTÓRIA DE EMPRESAS. 3., 1999, Curitiba. Anais...1 CD-ROM.

SOMMER, R. Deutsche Telekom Conference Call. Apresentação em Acrobat Reader do Chief Executive Officer da Deutsche Telekom em 18 de maio de 1999. Disponível em: <www.telecomitalia.it> Acesso em: jun. 1999.

TELECOM ITALIA. Disponível em: <www.telecomitalia.it/chisiamo/ 24129@txt.uk.shtml> Acesso em: 10 jun. 2001.

. Disponível em: <www.telecomitalia.it> Acesso em: 30 jun. 1999.

TELEFÓNICA. Disponível em: <www.telefónica.es> Acesso em: 30 jun. 1999. 
TIGRE, P .B.; SARTI, F. Tecnologia da informação, mudanças organizacionais e impactos sobre o trabalho. Rio de Janeiro: SENAI/DN/CIET, 1997, 58 p.

TIGRE, P. B. Comércio eletrônico e globalização: desafios para o Brasil. In: LASTRE, H. M. M.; ALBAGLI, S. (Org.) Informação e globalização na era do conhecimento. Rio de janeiro: Campus, 1999. p. 84-104.

. Inovações e teorias da firma em três paradigmas. Revista de Economia Contemporânea, IE./UFRJ, n. 3, 1999.

.; LA ROVERE, R.; FAGUNDES, J. Tecnologias da informação e desenvolvimento: novas evidências sobre sua difusão e impactos econômicos. IE/UFRJ, 1995, 41 p. Revista Brasileira de Economia.

VONORTAS, N. S.; SAFIOLEAS, S. P. Strategic alliances in information technology and developing country firms: recent evidence. World Development, v. 25, n. 5, p. 657-680, 1997.

WAVERMAN, L.; SIREL, E. European telecommunications markets on the verge of full liberalization. Journal of Economic Perspective, v. 11, n. 4, p. 113-126, Fall, 1997.

YOSHINO, M. Y. Alianças estratégicas. São Paulo: Makron Books, 1997, p. 3-92. 